\title{
Use of Inhibitors for Selective Isolation and Enumeration of Cytophagas from Natural Substrates
}

\author{
By G. M. WARKE AND S. A. DHALA \\ Department of Microbiology, Bhavan's College, Andheri, Bombay 58, India \\ (Accepted for publication 4 September 1967)
}

\begin{abstract}
Several antibacterial agents were tested against a range of cytophagas and other bacteria representing types commonly found in soil and marshy places. From these tests two antibiotics (penicillin I 5 units $/ \mathrm{ml}$. and chloramphenicol $5.0 \mu \mathrm{g} . / \mathrm{ml}$.) and two bile salts (sodium taurocholate $8.0 \mathrm{mg} . / \mathrm{ml}$. and sodium cholate $6.0 \mathrm{mg} . / \mathrm{ml}$.) were selected for incorporation into alkaline enrichment media to achieve selective growth of cytophagas. This mixture of antibiotics and bile salts was tested with a number of soils and its efficiency compared with several other methods for selective development of cytophagas; bile salts inhibited two common species. The most suitable mixture for the selection of cytophagas was enrichment medium with penicillin and chloramphenicol.
\end{abstract}

\section{INTRODUCTION}

The current methods for primary isolation of soil cytophagas orient around enrichment in liquid media containing cellulose or chitin, followed by streaking on solid media with the same enrichment. The isolation methods recommended by Bachman (1955), Stanier (I942) and Veldkamp (196I) entail several transfers in the elective environment. Although antibiotics have been commonly used in media to select actinomycetes, fungi and other bacteria, they have not been used for selective isolation of cytophagas, with the exception of actidione for the isolation of fruiting myxobacteria (Brockman \& Boyd, 1963). However, this antifungal antibiotic has a restricted action against bacteria, which are the usual contaminants. Therefore, it was decided to make a study of the value of antibacterial agents for the selection of cytophagas. The inhibitors were tested in glucose mineral salt solution (Stanier, 1942), mineral chitin agar (Stanier, 1947) and Veldkamp medium (Veldkamp, 196I), commonly used for the study of cytophagas. The effect of antibiotics and bile salts on pure cultures of soil-inhabiting cytophagas was earlier reported (Warke \& Dhala, I966) where penicillin, chloramphenicol and bile salts were incorporated in alkaline enrichment media in several comparative experiments.

\section{METHODS}

The cellulolytic, chitinoclastic and facultative anaerobic Cytophaga species (Table I) earlier isolated by enrichment techniques were maintained, grown and tested on glucose mineral salt solution, mineral chitin agar and Veldkamp's agar, respectively.

Testing of inhibitors against cytophagas and other bacteria. Minimal inhibitory concentrations (m.i.c.) of sodium penicillin G (Pfizer) and chloramphenicol (Pfizer), were determined by the tube dilution method; solutions of the antibiotics were prepared 
in sterile water and added to give concentrations of chloramphenicol $5 \cdot 0-6 \cdot 5 \mu \mathrm{g} . / \mathrm{ml}$. and $\mathrm{Na}$ penicillin $\mathrm{G}$ I0, I5, 20 and $25 \mathrm{units} / \mathrm{ml}$. Aqueous solutions of bile salts $10 \%$ $(\mathrm{w} / \mathrm{v})$ were sterilized at $12 \mathrm{I}^{\circ}$ for $20 \mathrm{~min}$. and added to give $5, \mathrm{IO}, \mathrm{I} 5 \mathrm{and} 20 \mathrm{mg} . / \mathrm{ml}$. Tests were run in tubes, each containing $5 \mathrm{ml}$. Pen-assay broth (Difco). The tubes were inoculated to give $2 \times 10^{6}$ organisms $/ \mathrm{ml}$. The cultures were inoculated and incubated at $28^{\circ}$ for $48 \mathrm{hr}$, and the degree of growth determined in terms of turbidity measurements with a Klett-Summerson colorimeter at $450 \mathrm{~m} \mu$. The inhibitory effect was further confirmed by streaking loopfuls from dilution tubes on to a nutrient agar surface. The reaction of some common soil bacteria which grew in the enrichment medium, e.g. Cellulomonas, Desulphovibrio, Pseudomonas, Bacillus and Nocardia species earlier isolated from enrichment tubes, was tested against the selected concentrations of inhibitors (Table 2); the inhibitors were incorporated in glucose mineral agar for Cellulomonas, Cellvibrio, Desulphovibrio and Pen-assay agar (Difco) for the rest.

Table I. Effect of penicillin, chloramphenicol and bile salts on various Cytophaga species

\begin{tabular}{|c|c|c|c|c|}
\hline \multirow[b]{2}{*}{ Cytophaga species } & \multicolumn{4}{|c|}{ Minimal inhibitory concentration } \\
\hline & $\begin{array}{l}\text { Penicillin } \\
\text { (units/ml.) }\end{array}$ & $\begin{array}{l}\text { Chloram- } \\
\text { phenicol } \\
(\mu \mathrm{g} . / \mathrm{ml} .)\end{array}$ & $\begin{array}{l}\text { Sodium } \\
\text { taurocholate } \\
\text { (mg./ml.) }\end{array}$ & $\begin{array}{l}\text { Sodium } \\
\text { cholate } \\
(\mathrm{mg} . / \mathrm{ml} .)\end{array}$ \\
\hline Cytophaga hutchinsonii & 25 & 6.0 & $20 \cdot 4$ & $20 \cdot 0$ \\
\hline C. lutea & 15 & $5 \cdot 0$ & I $5 \cdot 8$ & $16 \cdot 0$ \\
\hline C. rubra & 18 & $5 \cdot 0$ & - & 一 \\
\hline C. tenuissima & 15 & $5 \cdot 5$ & - & - \\
\hline C. aurantiaca & I5 & $5 \cdot 5$ & $6 \cdot 4$ & $8 \cdot 0$ \\
\hline C. albogilva & 20 & $6 \cdot 0$ & $15 \cdot 0$ & $13 \cdot 3$ \\
\hline C. deprimata & 20 & $6 \cdot 0$ & $16 \cdot 0$ & 13.0 \\
\hline C. johnsonii & 26 & $5 \cdot 5$ & II $\cdot 0$ & $12 \cdot 0$ \\
\hline C. fermentans & 29 & $6 \cdot 0$ & $20 \cdot 0$ & 15.8 \\
\hline $\begin{array}{l}\text { C. fermentans } \\
\text { var. agarovorans }\end{array}$ & 25 & $6 \cdot 3$ & $19 \cdot 5$ & $17 \cdot 5$ \\
\hline C. salmonicolor & 27 & $6 \cdot 7$ & $19 \cdot 8$ & $15 \cdot 75$ \\
\hline
\end{tabular}

Comparison of soil enrichment tubes with and without inhibitors. From the results of tests with pure cultures, experiments were done to study the effect of the inhibitors on colony counts on dilution plates prepared from several soil and mud samples. The soils

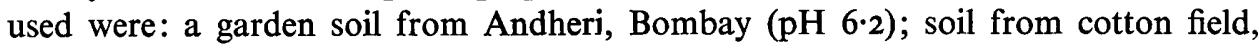
College campus, Bombay ( $\mathrm{pH} 5.9$ ); manured soil from Bandra, Bombay ( $\mathrm{pH} 6 \cdot 0$ ); two

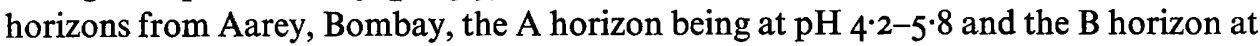
$\mathrm{pH} 7 \cdot 2-8 \cdot 6$; two marshy soils from Versova and Danda, Bombay, at $\mathrm{pH} 6 \cdot 7-7 \cdot \mathrm{I}$. These soils differed considerably in their total microbial contents and the relative proportion of cytophagas to other bacteria.

Isolation. Soil (I g.) was added to $100 \mathrm{ml}$. sterile water in screw-top bottles and shaken on a reciprocal shaker for $30 \mathrm{~min}$. Tenfold dilutions were prepared from the resulting suspension and $0.1 \mathrm{ml}$. of $10^{-3}$ and $\mathrm{IO}^{-4}$ dilutions were used to seed $10 \mathrm{ml}$. of the enrichment medium (Stanier, 1942). The inhibitors when used were added to enrichment medium just before inoculation at the following concentration: $\mathrm{Na}$ penicillin G 15 units $/ \mathrm{ml}$.; chloramphenicol $5.0 \mu \mathrm{g} . / \mathrm{ml}$.; bile salts $5.0 \mathrm{mg} . / \mathrm{ml}$. Experiments were run in 15 sets for each dilution. Tubes were incubated at $28^{\circ}$ for 8 days; 
slimy patches from the cellulose strips were scraped out with a platinum needle and streaked on corresponding sets of solid media with $0.75 \%$ agar (U.S.P., Japan) and $0.5 \%$ glucose instead of cellulose. Re-streakings on fresh media were often necessary to obtain pure cultures. Besides these media, starch agar and cellulose + dextrin agar (Fuller \& Norman, 1942) containing the inhibitors were also used in the isolation of Cytophaga albogilva and C. deprimata. Chitinoclastic cytophagas were isolated by inoculating I g. soil in a flask containing Stanier's basal medium (1947) with and without inhibitors and with chitin strips (prepared from lobster shells; Stanier, 1947) as sole source of carbon. Growth from chitin strips after 8 days of incubation at $28^{\circ}$ was streaked on mineral chitin agar. Facultative agar-decomposing cytophagas were enriched according to Veldkamp's technique (1961) with the inhibitory substances incorporated in enrichment medium.

Table 2. The reaction of some cytophagas and other bacteria to inhibitors

\begin{tabular}{|c|c|c|c|}
\hline Inhibitors & $\begin{array}{l}\text { Completely } \\
\text { inhibited }\end{array}$ & $\begin{array}{l}\text { Partially } \\
\text { inhibited }\end{array}$ & $\begin{array}{c}\text { Not } \\
\text { inhibited }\end{array}$ \\
\hline $\begin{array}{l}\text { Penicillin (I5 units } / \mathrm{ml} .)+ \\
\text { chloramphenicol } \\
(5.0 \mu \mathrm{g} . / \mathrm{ml} .)(a)\end{array}$ & $\begin{array}{l}\text { Cellulomonas, } \\
\text { Nocardia } \\
\text { Pseudomonas species }\end{array}$ & $\begin{array}{l}\text { Desulphovibrio and } \\
\text { Cellvibrio species, } \\
\text { Bacillus subtilis }\end{array}$ & Cytophaga species* \\
\hline $\begin{array}{l}\text { Sodium taurocholate }+ \\
\text { sodium cholate } \\
(5.0 \mathrm{mg} . / \mathrm{ml} ., \text { each })(b)\end{array}$ & $\begin{array}{l}\text { Cytophaga rubra, } \\
\text { C. tenuissima } \\
\text { Nocardia } \\
\text { Bacillus species }\end{array}$ & $\begin{array}{l}\text { Cellulomonas, } \\
\text { Desulphovibrio } \\
\text { Cellvibrio species }\end{array}$ & $\begin{array}{l}\text { Cytophaga species* } \\
\text { except } C \text {. rubra } \\
C . \text { tenuissima }\end{array}$ \\
\hline$a+b$ & $\begin{array}{l}\text { C. rubra, } \\
\text { C. tenuissima } \\
\text { Nocardia, } \\
\text { Pseudomonas, } \\
\text { Cellulomonas } \\
\text { Bacillus species }\end{array}$ & $\begin{array}{l}\text { Cellfalcicula, } \\
\text { Desulphovibrio } \\
\text { Cellvibrio } \\
\text { species }\end{array}$ & $\begin{array}{l}\text { Cytophaga species* } \\
\text { except } C \text {. rubra } \\
\text { C. tenuissima }\end{array}$ \\
\hline
\end{tabular}

\section{RESULTS}

Testing of inhibitors against cytophagas and other bacteria

Of the four inhibitors tested against a range of cytophagas, penicillin ( 15 units $/ \mathrm{ml}$.) and chloramphenicol $\left(5^{\circ} \circ \mu \mathrm{g} . / \mathrm{ml}\right.$.) at $\mathrm{pH} 9 \cdot 0$ were tolerated by all the tested strains. It is evident from Table I that bile salts were well tolerated by the majority of cytophagas, except for Cytophaga rubra and $C$. tenuissima, which were highly sensitive to bile salts. It was decided to test the sensitivity of the strains against a mixture of penicillin, chloramphenicol and bile salts in various concentrations at $\mathrm{pH} 9 \cdot 0$.

\section{The reaction of some bacteria to inhibitors}

Details of the reaction of the individual Cytophaga species and some common contaminants to the inhibitory mixtures are given in Table 2. The results were like those previously obtained; only the presence of bile suppressed the growth of some cellulolytic cytophagas. 


\section{Comparison of soil enrichment tubes with and without inhibitors}

Results obtained with enrichment medium with and without inhibitors are given in Table 3. It is seen that the isolation of cytophagas was facilitated since the ratio of cytophaga to bacteria was increased, whereby the chances of isolation are enhanced. Similarly, incorporation of the antibiotics and bile salts decreased the number of secondary transfers in enrichment media and made it possible to obtain cytophagas directly on the dilution plate. The usefulness of the inhibitory substances was seen with all types of Cytophaga, namely cellulolytic, chitinoclastic and also facultatively anaerobic agar-decomposing forms.

Table 3. Selective enrichment medium for the isolation of cytophagas

\begin{tabular}{|c|c|c|c|c|c|c|}
\hline \multirow[b]{3}{*}{ Media } & \multicolumn{6}{|c|}{ Type of cytophagas } \\
\hline & \multicolumn{2}{|c|}{ Cellulolytic } & \multicolumn{2}{|c|}{ Chitinoclastic } & \multicolumn{2}{|c|}{ Facultative anaerobes } \\
\hline & $\begin{array}{l}\mathrm{C} \text { to } \mathrm{B}^{*} \\
\text { ratio }\end{array}$ & $\begin{array}{l}\text { No. of } \\
\text { secondary } \\
\text { transfers } \\
\text { in EM }\end{array}$ & $\begin{array}{c}\mathbf{C} \text { to } \mathrm{B} \\
\text { ratio }\end{array}$ & $\begin{array}{l}\text { No. of } \\
\text { secondary } \\
\text { transfers } \\
\text { in EM }\end{array}$ & $\begin{array}{l}\mathrm{C} \text { to } \mathrm{B} \\
\text { ratio }\end{array}$ & $\begin{array}{l}\text { No. of } \\
\text { secondary } \\
\text { transfers } \\
\text { in EM }\end{array}$ \\
\hline EM† & $1: 60$ & 3 & $1: 65 \cdot 5$ & 2 & I : 70 & 3 \\
\hline $\mathrm{EM}+$ sodium taurocholate (EMT) & $1: 33$ & 2 & $1: 37$ & $\mathbf{I}$ & $\mathrm{I}: 30 \cdot 5$ & I \\
\hline EM + sodium cholate (EMC) & $I: 34$ & 2 & $1: 35 \cdot 2$ & $\mathbf{I}$ & I:29 & $\mathbf{I}$ \\
\hline EM + penicillin (EMP) & $1: 38$ & 2 & $\mathrm{I}: 4 \mathrm{I}$ & $\mathbf{I}$ & $1: 38$ & 2 \\
\hline $\mathrm{EM}+$ chloramphenicol (EMCh) & $1: 30$ & 2 & $1: 32$ & $\mathbf{I}$ & I $: 28 \cdot 5$ & $\mathbf{I}$ \\
\hline EM pH 8.5 (EM 8.5) & $1: 31$ & 2 & $1: 30 \cdot 5$ & I & $1: 27 \cdot 3$ & I \\
\hline EMT + sodium cholate & $\mathrm{I}: \mathbf{2 8}$ & I & $I: 25 \cdot 5$ & Nil & I $: 23.5$ & Nil \\
\hline EMT + penicillin & I :22 & I & $\mathrm{I}: 22$ & Nil & $\mathrm{I}: 20 \cdot 2$ & Nil \\
\hline EMT + chloramphenicol & I $: 20$ & Nil & $\mathrm{I}: 2 \mathrm{I}$ & Nil & $I: 18 \cdot 5$ & $\mathrm{Nil}$ \\
\hline EMC + penicillin & $1: 18 \cdot 3$ & $\mathrm{Nil}$ & $1: 19$ & Nil & $1: 16 \cdot 2$ & Nil \\
\hline EMC+ chloramphenicol & $1: 17 \cdot 2$ & Nil & $\mathrm{I}: \mathrm{I} 6$ & Nil & $1: 15 \cdot 3$ & Nil \\
\hline EM $8 \cdot 5+$ sodium cholate & I : $15 \cdot 3$ & Nil & $\mathrm{I}: 14$ & Nil & $1: 13 \cdot 2$ & Nil \\
\hline EM 8.5 + sodium taurocholate & $I: 14: 5$ & Nil & $\mathrm{I}: 14$ & Nil & $1: 13 \cdot 7$ & Nil \\
\hline EM $8.5+$ chloramphenicol & $\mathbf{I}: \mathbf{I} 3$ & Nil & $1: \mathbf{1} 3 \cdot 2$ & $\mathrm{Nil}$ & $I: 12 \cdot 5$ & Nil \\
\hline EMCh + penicillin & I : $12 \cdot 5$ & Nil & I: $: 13$ & Nil & $1: 11 \cdot 6$ & Nil \\
\hline
\end{tabular}

\section{Comparison of plate counts obtained on alkaline cytophaga agar medium, unsupplemented and with four inhibitors}

Plate counts of Cytophaga colonies were made for seven soil samples on alkaline Cytophaga agar containing penicillin + chloramphenicol + bile salts, the same medium with only antibiotics, and two other media selective for cytophagas. Details of these results are given in Table 4 . When the percentages of colonies on plates were considered, the alkaline Cytophaga agar with antibiotics gave results almost similar to those obtained with the medium containing four inhibitors. Unsupplemented alkaline Cytophaga agar medium had only 4 - I I \% of Cytophaga colonies out of the total colonies developing on plates, indicating a good selectivity of the supplemented media. 


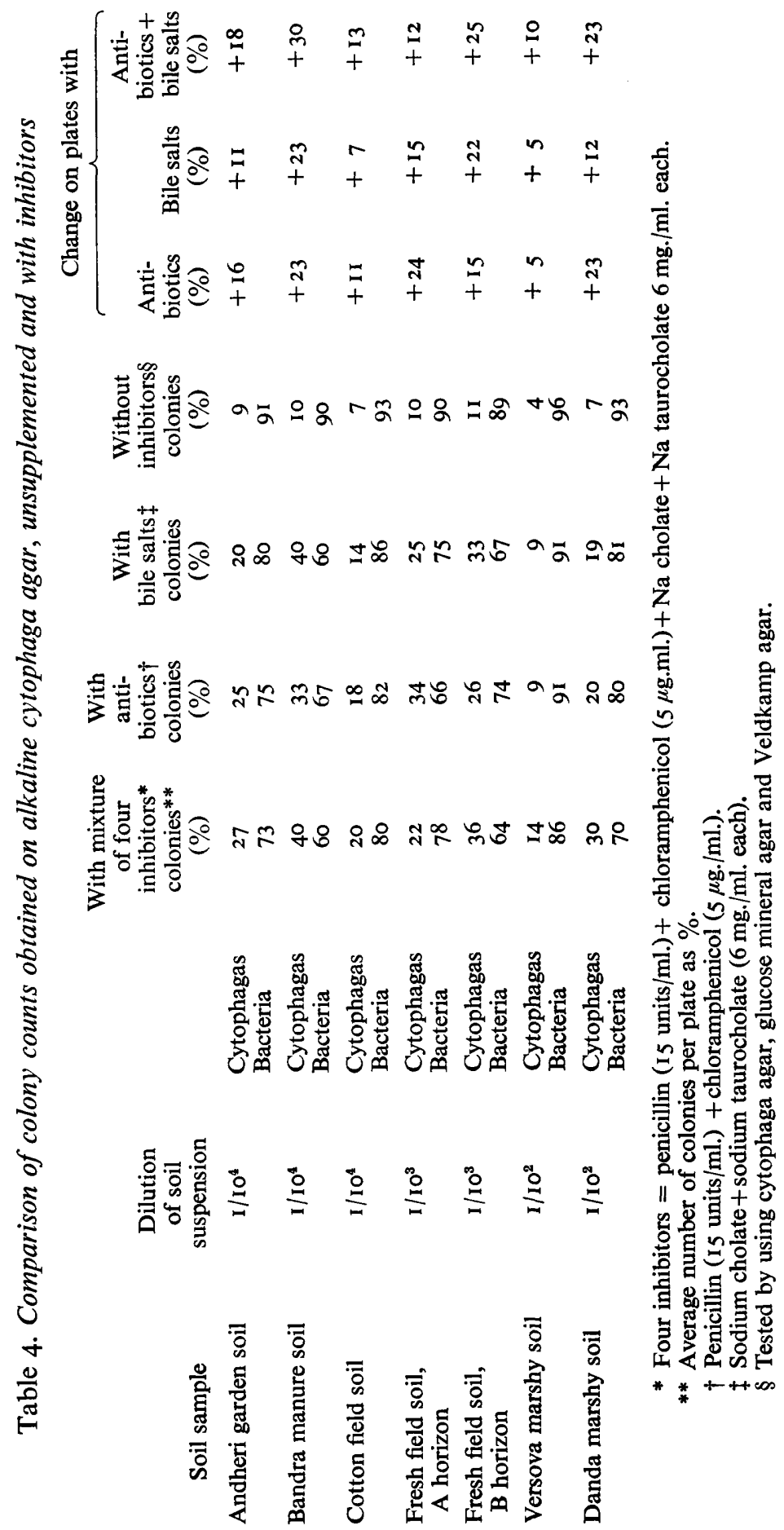




\section{DISCUSSION}

The proportion of cytophagas to the other micro-organisms in most soil samples is very small; this limits the use of the dilution method for isolations. Besides, the cytophagas exhibit a spreading type of growth and carry along the contaminants, which remain embedded in their slime in several subcultures. The sensitivity of cytophagas to heat above $40^{\circ}$ and their loss of pigmentation even at $37^{\circ}$ (Warke \& Dhala, 1966) rules out attempts to restrict the growth of other bacteria by heat treatment. The common method of isolation of cellulolytic cytophagas depends particularly on the formation of coloured patches on filter-paper strips (Stanier, 1942; Fuller \& Norman, 1943); these usually have many non-cellulolytic and non-myxobacterial forms which thrive on breakdown products of cellulose produced by a few cellulolytic varieties. Similarly, the chitin strips underwent a slow decomposition accompanied by the development of a varied microflora, particularly of chitin-decomposing eubacteria, from which cytophagas could not be readily obtained. However, these eubacteria were easily suppressed in selective media where the cytophagas were often observed to be the only chitin decomposers. The facultative anaerobes could likewise be equally well isolated from marine sources. A great advantage of the inhibitors tested was noticed in the isolation of marine forms, where blackening of the enrichment media was prevented since the sulphur-reducing bacteria were also eliminated.

Although Bachmann (1955) reported a failure to develop a more suitable method for enrichment of facultatively anaerobic cytophagas, Cytophaga fermentans was readily isolated by the incorporation of penicillin (I 5 units $/ \mathrm{ml}$.) + chloramphenicol $\left(5^{\circ} 0 \mu \mathrm{g} . / \mathrm{ml}\right.$.) in isolation media.

It was noticed that of the seven soil samples (Table 4) examined for Cytophaga species by the dilution method, with and without inhibitors, almost all the samples which yielded cytophagas in absence of the inhibitors also gave the same species in presence of the inhibitors (either singly or mixed) except for bile salts, which were toxic to Cytophaga tenuissima and C. rubra.

It is felt that the use of inhibitors can be applied profitably in future studies on the isolation of cytophagas from natural sources.

\section{REFERENCES}

Bachmann, B. J. (1955). Studies on Cytophaga fermentans, n.sp., a facultatively anaerobic lower myxobacterium. J. gen. Microbiol. 13, 54I.

Brockman, E. R. \& Boyd, W. L. (1963). Myxobacteria from soils of the Alaskan and Canadian Arctic. J. Bact. 86, 605 .

Fuller, W. H. \& Norman, A. G. (1942). A cellulose-dextrin medium for identifying cellulose organisms in soil. Proc. Soil Sci. Soc. Am. 7, 243.

Fuller, W. H. \& Norman, A. G. (I943). Characteristics of some soil cytophagas. J. Bact. 45, 565.

STANIER, R. Y. (I942). The Cytophaga group: a contribution to the biology of myxobacteria. Bact. Rev. 6, 143.

STANIER, R. Y. (I947). Studies on nonfruiting myxobacteria. I. Cytophaga johnsonae, n.sp., a chitindecomposing myxobacterium. J. Bact. 53, 297.

VELDKAMP, H. (I961). A study of two marine agar-decomposing, facultatively anaerobic myxobacteria. J. gen. Microbiol. 26, 331.

Warke, G. M. \& DhalA, S. A. (1966). Effect of heat and antimicrobial agents on Cytophaga sp. isolated from various substrates in Bombay. Indian J. Microbiol. 6, 5. 